\title{
Sunlight Therapy and Solar Architecture
}

\author{
R A HOBDAY*
}

At the present time sunbathing is being actively discouraged by medical authorities, ${ }^{1}$ yet little more than fifty years ago it was quite common for sunlight to be prescribed in the treatment of tuberculosis and other diseases. During the First World War sunlight therapy or, as it became known, heliotherapy was used to heal the wounds of casualties on both sides of the conflict; and in the years that followed a number of hospitals and clinics were built so that tuberculosis patients could be exposed to solar radiation under medical supervision.

The therapeutic properties of ultra-violet light came to the attention of the medical profession during the early years of this century. This was due, in no small part, to the work of Dr Niels Finsen (1860-1904), who was the first physician both to use sunlight in clinical practice and to investigate its effects scientifically. Finsen was awarded the second Nobel Prize for Medicine in 1903 for his success in treating tuberculosis of the skin with ultra-violet light; and he is best remembered for his work with concentrated ultra-violet rays from specially constructed carbon-arc lamps which became known as "Finsen Lamps". His investigations of the effects of sunbathing on tuberculosis of the bones and joints, and on pulmonary tuberculosis ${ }^{2}$ are perhaps less well known, and it is the Swiss physician Dr Oskar Bernhard (1861-1939) who is generally regarded as the first heliotherapist of the modern era. In 1902 Bernhard discovered the beneficial effects of sunlight on torpid wounds and subsequently exposed tuberculosis patients to the sun's rays. A year later, in 1903, another Swiss physician, Dr Auguste Rollier (1874-1954) began to use sun baths at a tuberculosis clinic at Leysin, Switzerland, and went on to become heliotherapy's most celebrated practitioner.

\section{Surgical Tuberculosis}

At the turn of the century tuberculosis was a very common disease. According to a contemporary estimate, it claimed more than 1 million lives in Europe each year ${ }^{3}$ and figures for England and Wales show that it caused the deaths of about 1 in every 8 of the

*Dr R A Hobday, 204 Sellywood Road, Bournville, Birmingham B30 1TJ.

I should like to thank Madame Chapuis-Rollier for permission to reproduce the photographs of Professor Rollier's clinics. I am also very grateful to the following for their assistance during the preparation of this article: Monsieur Maurice Andre of Leysin, Mrs Janice Mayhew of the Lord Mayor Treloar Hospital, Mr Robert Taylor, formerly of the Royal Commission on the Historical Monuments of
England, Mr John Palmer of John Palmer Associates, and the late Mr A J Howrie.

1 J G Ainsleigh, 'Beneficial effects of sun exposure on cancer mortality', Prev. Med., 1993, 22: 132-40, p. 132.

2 S Lomholt, 'De første sollysbade for tuberkulose_en halvt forglemt episode', Ugeskrift for Laeger, 25 Sept. 1930, 92: 915-16.

${ }^{3}$ Anon., The Practitioner, June 1898, 60: 286. 


\section{R A Hobday}

population. ${ }^{4}$ The most common form of the disease was tuberculosis of the lungs, referred to as consumption, or phthisis, which mainly affected adults. ${ }^{5}$ Where treatment for pulmonary tuberculosis was available, it usually took the form of the "open-air" methods first formulated in 1840 by Dr George Bodington (1799-1882), ${ }^{6}$ in which consumptive patients were sent away to sanatoria to undergo a regime of rest, diet therapy, light exercise and exposure to fresh air. While numerous sanatoria were available to adult patients in Europe and North America, open-air sanatoria specifically for children appear to have been exceptional. ${ }^{7}$ This was because children and adolescents were more susceptible to tuberculosis of the bones, joints and glands ${ }^{8}$ and the remedy generally administered was radical, intensive surgery, ${ }^{9}$ so much so, that the extra-pulmonary form of the disease was commonly referred to as surgical tuberculosis.

The view gradually gained ground that radical surgery was not necessarily the best treatment, as operations on bones and joints, especially in childhood, were found to have a serious effect on growth and led to a disfiguring shortening of limbs, and stiff joints. After the removal or destruction of tubercular foci, and even after amputations, patients were still generally far from being cured. Local recurrences, or a general tubercular infection, were often the sequel to surgery in patients already weakened by disease. ${ }^{10}$ So physicians began to adopt so-called "conservative" measures such as open-air methods and heliotherapy in an attempt to improve patients' general health, increase their resistance to tuberculous disease, and preserve or restore the part or parts affected. The adoption of heliotherapy in such cases led to a number of institutions being built specifically for the treatment with sunlight of non-pulmonary tuberculosis.

\section{Sanatoria and Sunlight}

In architectural terms it is often difficult to distinguish between open-air sanatoria for pulmonary tuberculosis, and heliotherapy clinics for surgical tuberculosis, as both were oriented for sunlight: but for different reasons. Open-air sanatoria were designed to admit sunlight in an attempt to kill bacteria and prevent the cross- and re-infection of patients. In 1877 Arthur Downes and T P Blunt had shown that light had a bactericidal effect ${ }^{11}$ and in 1882 the German bacteriologist Robert Koch had discovered the tubercle bacillus (Mycobacterium tuberculosis) and proved that it caused the disease. In 1890 Koch carried out further experiments which showed that sunlight was lethal to the bacillus. ${ }^{12}$ Once it was recognized that the bacilli were present in the expectorated mucus or phlegm of

\footnotetext{
${ }^{4} \mathrm{~L}$ Bryder, Below the magic mountain: a social history of tuberculosis in twentieth-century Britain, Oxford, Clarendon Press, 1988, p. 1.

5 Ibid., p. 3.

${ }^{6}$ George Bodington, An essay on the treatment and cure of pulmonary consumption, on principles natural, rational and successful, Longmans, 1840, reprinted in Selected essays and monographs, London, New Sydenham Society, 1901.

${ }^{7} \mathrm{~F}$ B Smith, The retreat of tuberculosis, 1850-1950, London, Croom Helm, 1988, p. 13.

${ }^{8}$ Bryder, op. cit., note 4 above, p. 3.

9 A J Carter, 'Hugh Owen Thomas: the cripple's champion', Brit. med. J., 1991, 303: 1578-81, p. 1580.
}

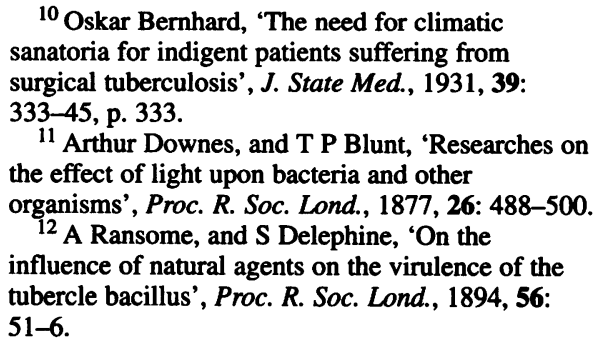

${ }^{10}$ Oskar Bernhard, 'The need for climatic sanatoria for indigent patients suffering from surgical tuberculosis', J. State Med., 1931, 39: $333-45$, p. 333.

11 Arthur Downes, and T P Blunt, 'Researches on the effect of light upon bacteria and other organisms', Proc. R. Soc. Lond., 1877, 26: 488-500.

${ }^{12}$ A Ransome, and S Delephine, 'On the influence of natural agents on the virulence of the tubercle bacillus', Proc. R. Soc. Lond., 1894, 56: $51-6$. 


\section{Sunlight Therapy and Solar Architecture}

infected individuals, and that dried tuberculous sputum or tuberculous dust could infect people who were in a condition to contract the disease, designers of sanatoria were encouraged to exploit the germicidal properties of sunlight:

... every room occupied or visited by patients should be flooded by sunlight whenever possible, because, of all disinfectants, sunlight has been shown to be the most powerful. It is perhaps, together with pure air, the only certain non-liquid disinfectant for the tubercle bacillus. ${ }^{13}$

Although sanatoria were designed to be sunlit, facilities for sunbathing were not normally provided because heliotherapy did not form part of the open-air regime for pulmonary tuberculosis. Photographs of open-air sanatoria often show patients, in their beds, on balconies or verandas. They are covered by bedclothes and there is no evidence of any attempt to expose their bodies to direct sunlight. As an article in the Lancet of 1923 noted: "In the sanatorium treatment developed during the last 50 years, the action of direct sunlight plays no part, and no provision is made for it in the vast majority of sanatoriums."14 Institutions for the heliotherapy of surgical tuberculosis were, on the other hand, arranged so that sunlight could be clinically applied with the specific objective of tanning the patients to facilitate a cure. The physicians who carried out some of the formative work in this field were also active, directly or indirectly, in the design of such institutions.

\section{Dr Oskar Bernhard (1861-1939)}

Oskar Bernhard was born in Samaden, Switzerland, the son of a local chemist. He studied medicine at Zürich, Heidelberg and Berne, developing a particular interest in surgery. He returned to the Upper Engadine where he built up a large surgical practice and helped to establish the District Hospital at Samaden, which opened in $1898 .{ }^{15}$ Bernhard had been treating surgical tuberculosis with open-air methods, diet therapy and orthopaedic measures from the 1880 s onwards, but it was here, as surgeon-in-chief, that he began to use sunlight to heal first wounds and then tuberculosis. ${ }^{16}$

On the night of 2 February 1902, an Italian was brought to the hospital with severe knife wounds. These included a perforating wound of the chest, and two perforating wounds of the abdomen, with damage to the liver and spleen. As the injured man was in danger of bleeding to death, Bernhard had to extirpate the spleen, which had been pierced. Eight days after the laparotomy the operation wound burst open, and gaped widely, only the peritoneal stitches holding. An attempt to re-stitch the wound failed as the edges could not be brought together again. The wound was then packed with iodoform gauze and the edges drawn together as closely as possible with broad strips of plaster. It began to granulate slowly, but the granulation tissue was soft and spongy, and the whole wound discharged profusely. None of the treatments used to dry it up had any effect, so Dr Bernhard took the unusual step of exposing the wound to the sun:

\footnotetext{
${ }^{13}$ A Ransome, The principles of 'open-air' treatment of phthisis and of sanatorium construction, London, Smith, Elder, 1903, pp. 72-3.

${ }^{14}$ Anon., 'Natural and artificial sun cure in tuberculosis of the lungs', Annotations, Lancet, 1923, ii: $237-8$, p. 237.
}

\footnotetext{
15 K Flachsmann, Der Engadiner Arzt Oskar Bernhard (1861-1939) und die Begründung der Heliotherapie bei der chirurgischen Tuberkulose, Basel, Schwabe, 1966, p. 6.

${ }^{16}$ Ibid., p. 7.
} 


\section{R A Hobday}

As I entered the hospital one beautiful morning, and the sun shone warmly through the open window, while a refreshing and stimulating atmosphere filled the whole ward, the thought suddenly occurred to me of exposing this large wound to the sun and air; for the mountain peasant of the Grisons also exposes fresh pieces of flesh to the sun and dry air to preserve them, and in this way makes a nourishing and tasty food, the well-known "Bindenfleisch." So I resolved to try this antiseptic and drying effect of the sunlight and air on the living tissues. Then, to the great astonishment of the staff, I had the bed put to the open window and laid the large wound open. By the end of the first hour and a half's exposure there was a marked improvement noticeable, and the wound presented quite a different appearance. The granulations became visibly more normal and healthy, and the enormous wound skinned over quickly under the treatment. ${ }^{17}$

This success led him to treat all granulating and infective wounds with sunlight. He then began to treat open tuberculous cavities and, soon after, closed tuberculous foci of the bones, joints and glands with the sun's rays. ${ }^{18}$ The treatment took place either in the open air on a veranda, or in the sick-ward, and the procedure was to remove the dressings and expose the wounds to the sun for several hours daily. Where necessary he used a thin gauze curtain to keep off dust and flies, otherwise the wounds were unprotected. The duration of exposure was gradually lengthened; increasing every day by ten to twenty minutes up to a maximum of three to six hours, depending on the tolerance of the patient. After sunning, the wounds were left exposed to the air. At night, or at times when the wounds were not exposed to the sun, they were covered with an aseptic gauze bandage, or were protected from friction against the bedclothes by a wire cage made for the purpose. For large war wounds or large flesh wounds he used wire cradles which were held in place by plaster of Paris bandages. Bernhard preferred to use the full spectrum of the sun's rays and did not use concentrating lenses or try to filter off the heat rays as Finsen had done when treating tuberculosis. He did not recommend sunlight for fresh uninfected wounds or primary operation wounds. In his opinion these were best treated by an occlusive bandage. On the other hand he would not bandage wounds which discharged pus or sanious fluid: "Why should one hold up the secretion of infected wounds by thick bandages so that it may lead to great development of bacteria like an incubator? We do decidedly better with the sun and air treatment."19

Bernhard observed that when exposed to sunlight torpid wounds became clean and dry, and the granulations smaller and fresher. Also, discharging ulcers and pockets which would normally have required frequent changes of dressings, and even then often continued to discharge, dried up under the treatment. Apparently the discharge of badlysmelling wounds rapidly became odourless and, as well as cleansing the wounds, sunlight had a marked analgesic effect. ${ }^{20}$ When treating compound fractures he found that, besides stimulating the formation of callus, exposure to the sun had a favourable effect on the wounds themselves. ${ }^{21}$ Many authors regarded the pure drying power of the high mountain air as the chief factor in healing, but Bernhard claimed that direct sunning of wounds produced a more rapid and intense healing effect than diffuse sunlight or air. ${ }^{22}$

For many years Bernhard used only local sunning for wounds and tuberculosis: the diseased organ or injured part was exposed while the body remained covered. ${ }^{23} \mathrm{He}$ then

\footnotetext{
${ }^{17}$ Oskar Bernhard, Light treatment in surgery, London, Edward Arnold, 1926, pp. 156-7.

${ }^{18}$ Ibid., p. 157.

19 Ibid., p. 159.
}

${ }^{20}$ Ibid., p. 158.
21 Ibid., p. 196.
${ }^{22}$ Ibid., p. 161.
${ }^{23}$ Ibid., p. 239. 
became a convert to the full sun-bath, which he carried out by sunning the injured or diseased part until good local pigmentation had been achieved and then gradually proceeded to irradiate the whole body. ${ }^{24}$

\section{Bernhard's Heliotherapy of War Wounds}

During the early years of the First World War, Bernhard served in German military hospitals. In the summer of 1915 he began to use heliotherapy at Bad Dürrheim in the Black Forest. At the request of the Health Department of the 14th German Army Corps he started a sun clinic in the Association Hospital at Kindersolbad for soldiers with indolent wounds and external tuberculosis. ${ }^{25}$ Military sun-hospitals were then established at Dürrheim for wounded and sick soldiers from the whole German Army and the German military authorities designated Kindersolbad a "Special Department for Radiation Treatment". 26

From 1916 to 1917, Bernhard acted as Swiss Military Surgeon to prisoner-of-war camps in Germany, England and northern France. He visited the camps with the object of choosing prisoners to be sent to Switzerland for the after-treatment of wounds. ${ }^{27}$ During the course of his travels he saw that military surgeons were making extensive use of heliotherapy in the treatment of wounds. One hospital which he considered to be ideally arranged for this was the Duchess of Connaught Military Hospital which the Canadian Red Cross had built at Maidenhead on the property of the Astor family. ${ }^{28}$

In 1905, Bernhard had established his own small private clinic for sunlight therapy at St Moritz. ${ }^{29}$ It could accommodate some thirty-three patients ${ }^{30}$ and had south-facing balconies on two of the upper floors. This clinic is described in Bernhard's book of 1923, Sonnenlichtbehandlung in der Chirurgie, in which he put forward general design recommendations for heliotherapy wards and balconies and also outlined the plans for a more ambitious institution: a large sunlight-treatment clinic in the form of an amphitheatre with a large solarium on the roof, and open-air balconies built into the terraces which formed each storey. ${ }^{31}$ Although this was never realized, a number of other sizeable sunlight therapy clinics were built in Switzerland and elsewhere.

\section{Dr Auguste Rollier}

Oskar Bernhard's successes with sunlight brought him national and international recognition, but the physician who popularized heliotherapy as a remedy for tuberculosis was Dr Auguste Rollier (1874-1954), who began to use sunlight on his patients at a clinic at Leysin, Switzerland, in 1903. Rollier pioneered a form of treatment which was a development of open-air methods in which very slow tanning in cool conditions was combined with rest, fresh air, nourishment and exercise, with the aim of strengthening his patients and improving their resistance to the disease.

${ }^{24}$ Ibid., p. 240.

25 Ibid., pp. 164-5.

${ }^{26}$ Ibid., p. 166.

27 Ibid., p. 174.

${ }^{28}$ Ibid., p. 174.

${ }^{29}$ Flachsmann, op. cit., note 15 above, p. 7.

\footnotetext{
${ }^{30}$ Leonard E Hill, in Bernhard, op. cit., note 17 above, p. ix.

${ }^{31}$ Oskar Bernhard, Sonnenlichtbehandlung in der Chirurgie, Stuttgart, Ferdinand Enke, 1923, pp. 218-23.
} 


\section{R A Hobday}

Auguste Rollier was born on 1 October 1874, at St Aubin in the Swiss Canton of Neuchâtel. He was educated at the universities of Zürich and Berne, graduating in medicine in $1898 .{ }^{32}$ Like Bernhard before him, ${ }^{33}$ Rollier studied under Professor Theodor Kocher (1841-1917) at his surgical clinic in Berne and went on to become one of Kocher's assistants. Kocher was the pre-eminent surgeon in Europe at this time: he was awarded the Nobel Prize in 1909 for his work in surgery of the thyroid gland, and his book Operative surgery was the standard reference text for a generation of surgeons. ${ }^{34}$

Rollier appears to have became deeply disillusioned with the poor results obtained by surgery in the treatment of skeletal tuberculosis. Two developments led him to abandon a promising career in surgery and take up general practice. First, a close friend who had contracted tuberculosis while at school with Rollier and had had his hip and knee joint excised by Kocher returned for more surgery during the period when Rollier was Kocher's assistant. Unfortunately these operations did not cure the patient and his death seems to have left a deep impression on the young doctor. ${ }^{35}$ In addition, at the same time, Rollier's fiancée became seriously ill with pulmonary tuberculosis so, in the hope that the high mountain air would prolong her life (which it did), Rollier left Berne and went into a rural general practice at Leysin, in the Alpes Vaudoises. ${ }^{36}$

Rollier began to develop ideas on the general treatment of non-pulmonary tuberculosis which were based on his belief in the curative powers of sunshine and fresh air. Although he consulted Oskar Bernhard on the practice of open-air methods, ${ }^{37}$ the degree to which Bernhard influenced him in other respects is not altogether clear. Rollier appears to have been unaware that Bernhard had already begun to use the sun in $1902^{38}$ and, unlike Bernhard, from the outset Rollier advocated the general sun-bath as distinct from the local application of sunlight. ${ }^{39}$ Over the next forty years the technique Rollier devised for irradiating the body with sunlight came to be generally regarded as the best way to conduct heliotherapy.

\section{Rollier's Sunlight Therapy}

The method of slow tanning practised by Rollier was developed for debilitated patients who were often very seriously ill with tuberculosis and could not respond as well to sunlight as a healthy adult. ${ }^{40}$ For this reason, exposure was very gradual, and increased by only a few minutes each day. A series of short sunbaths three or four times a day produced better results than prolonged exposure. This was especially true of patients with pulmonary tuberculosis or tuberculosis of other internal organs. ${ }^{41}$

Rollier felt that the benefits of early-morning exposure to the sun were of particular importance, and he recommended that in the summer months the treatment should be

\footnotetext{
32 Anon., 'Auguste Rollier, M.D.', obituary, Brit. med. J., 1954, ii:1169-70, p. 1170.

${ }^{33}$ Flachsmann, op. cit., note 15 above, p. 6.

${ }^{34}$ Anon., 'Theodore Kocher (1841-1917) Bernese Burgher', J. Amer. med. Ass., 1967, 200 (3): 246-7, p. 247.

${ }^{35} \mathrm{P}$ De Kruif, Men against death, London, Jonathan Cape, 1933, pp. 299-300.

${ }^{36}$ Op. cit., note 32 above.

${ }^{37}$ Bernhard, op. cit., note 17 above, pp.15-16.
}

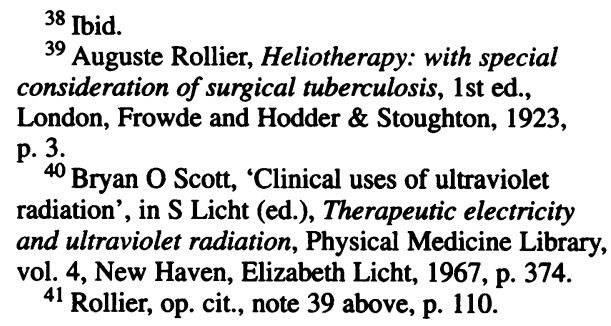
consideration of surgical tuberculosis, 1st ed., London, Frowde and Hodder \& Stoughton, 1923, p. 3 .

${ }^{40}$ Bryan O Scott, 'Clinical uses of ultraviolet radiation', in S Licht (ed.), Therapeutic electricity and ultraviolet radiation, Physical Medicine Library, vol. 4, New Haven, Elizabeth Licht, 1967, p. 374.

${ }^{41}$ Rollier, op. cit., note 39 above, p. 110. 


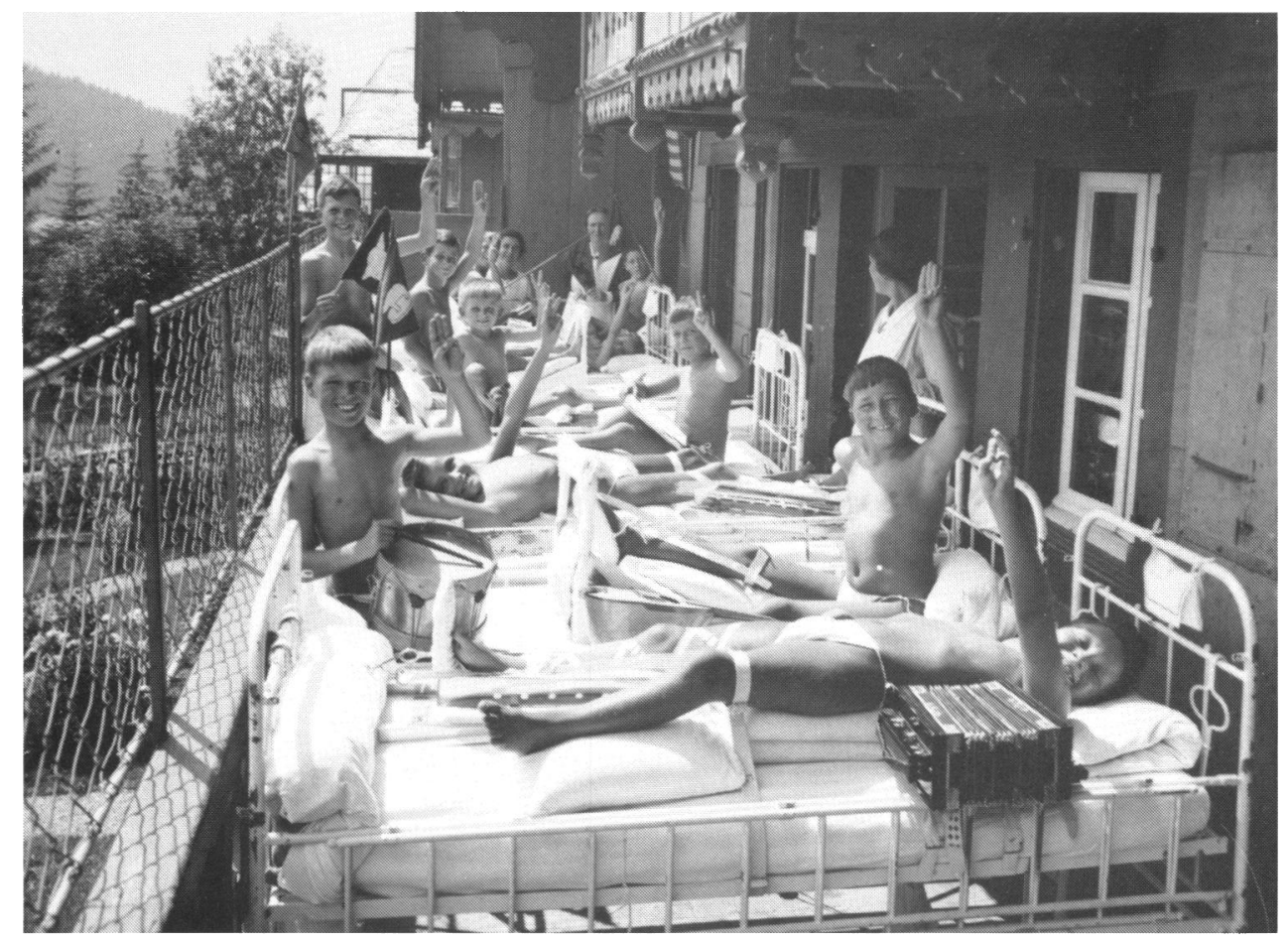

Plate 1: Patients at Rollier's first clinic Le Chalet (by permission of Dr Rollier's family).

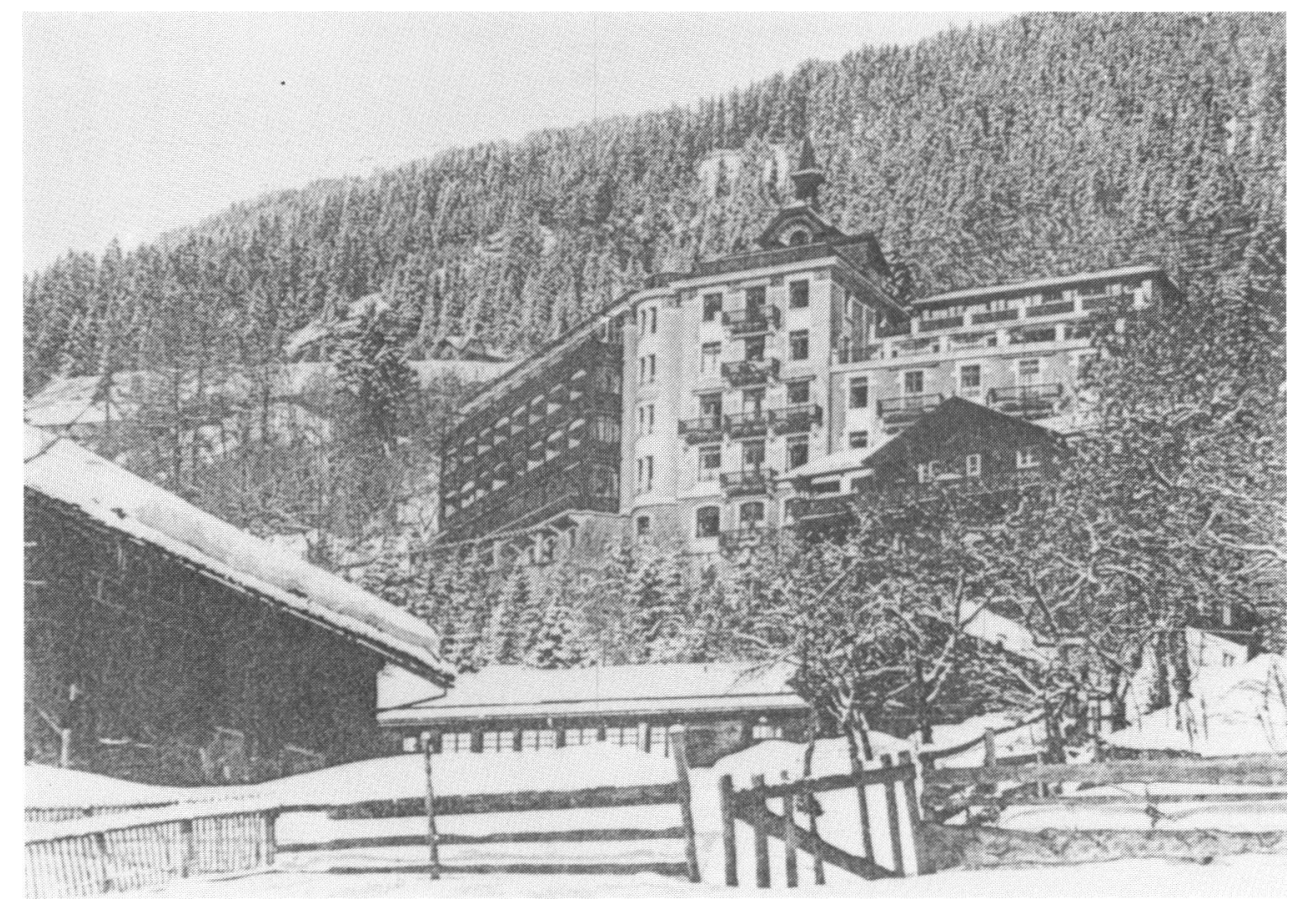

Plate 2: Rollier's clinic Les Frênes (by permission of Dr Rollier's family.) 


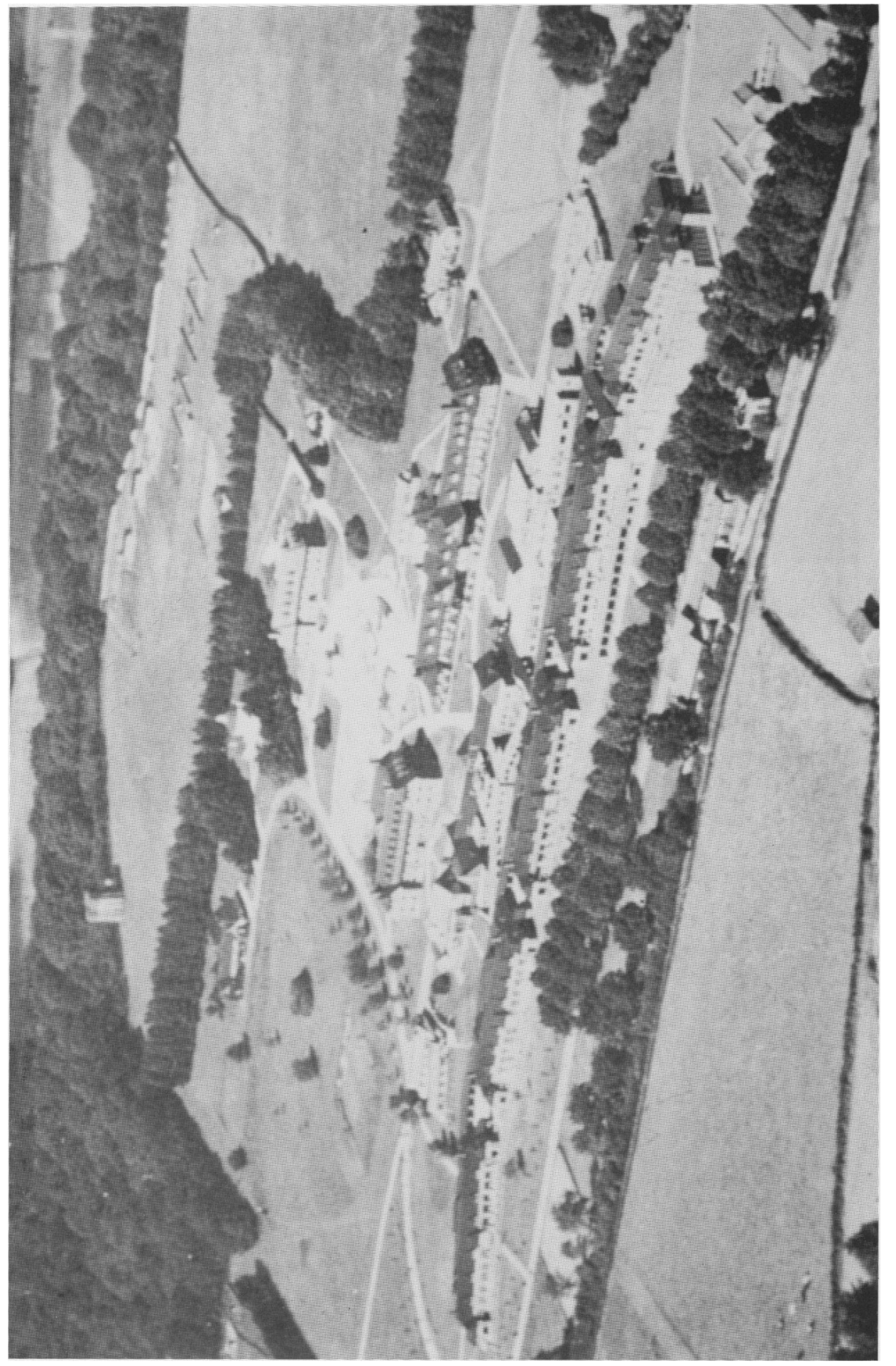

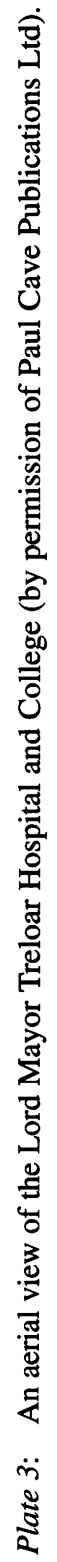




\section{Sunlight Therapy and Solar Architecture}

given between 6 a.m. and 9 a.m. -and at lower altitudes even earlier still-if the best results were to be achieved. ${ }^{42}$ The "heat" of the sun was avoided except where sunlight was used for the disinfection of wounds. ${ }^{43}$

Gradual exposure to cold air was important because it raised and maintained high metabolic activity in patients. This, in turn, was considered to improve their general health and to enable them to resist and overcome infection. Cool conditions and low winter and summer sun also reduced the risk of over-exposure to the sun's rays. Rollier regarded exposure to the sun at temperatures greater than $18^{\circ} \mathrm{C}$ to be a "hot-air bath" and not a sunbath. ${ }^{44}$ As he put it: "A very current mistake consists in thinking that the sun bath is all the more efficacious if prolonged or taken when the sun is at its hottest; this is an inconsistency against which Nature herself seems to warn us." 45

\section{Rollier's Technique}

Rollier considered that the safest way to sunbathe was by first exposing the lower, less sensitive parts of the body to the sun. He always began with the feet, and continued with the legs and arms, before exposing the abdomen and chest. By adopting this approach the tolerance of a patient to sunlight could be determined before the more sensitive parts of the body were uncovered. Also, if the patient received too much sunlight, only the extremities were involved and any adverse effects would be local rather than general. ${ }^{46}$ Rollier considered his method to be safe because it caused blood to flow away from the internal organs to the limbs, ${ }^{47}$ which he termed the "neutral" parts of the body. If this approach was not adopted, the result was likely to be congestion of blood in the viscera, with adverse consequences for the patient: haemoptysis and haemorrhage.

On arrival at Leysin his patients underwent a thorough medical examination. Then, after they had completed a period of acclimatization, they were carefully exposed to cold air. After one to two weeks of this open-air treatment, sunlight treatment could begin on the solaria and balconies of his clinics. Patients were wheeled out in their beds, each wearing a loincloth and covered in a white sheet from head to toe. Their heads were covered by hats or cloth screens. ${ }^{48}$

On the first day of treatment, the sheet was raised to just above the ankles, and the feet exposed to the sun for just five minutes. This was repeated twice with rest-periods of ten to fifteen minutes between each of the subsequent sunbaths. On the second day the sheet was raised to the knees, and the sunbath extended to ten minutes for each of the three sessions: the newly-uncovered lower legs were exposed for five minutes and the feet for ten. Exposure was gradually increased so that by the fifth day of treatment the patient had three sunbaths, each of twenty-five minutes' duration. The feet would be uncovered first, followed by the lower legs, the thighs, the abdomen and the chest: the feet would be exposed for the full twenty-five minutes, the legs for twenty, the thighs for fifteen, and so on. This is represented diagramatically in Figure 1.

\footnotetext{
42 Auguste Rollier, Heliotherapy, 2nd ed., London, Humphrey Milford and Oxford University Press, 1927, p. 47.

43 Idem, op. cit., note 39 above, p. 25.

44 Idem, op. cit., note 42 above, p. 47.

${ }^{45} \mathrm{Idem}$, "The share of the sun in the prevention
}

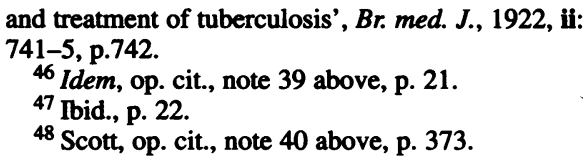




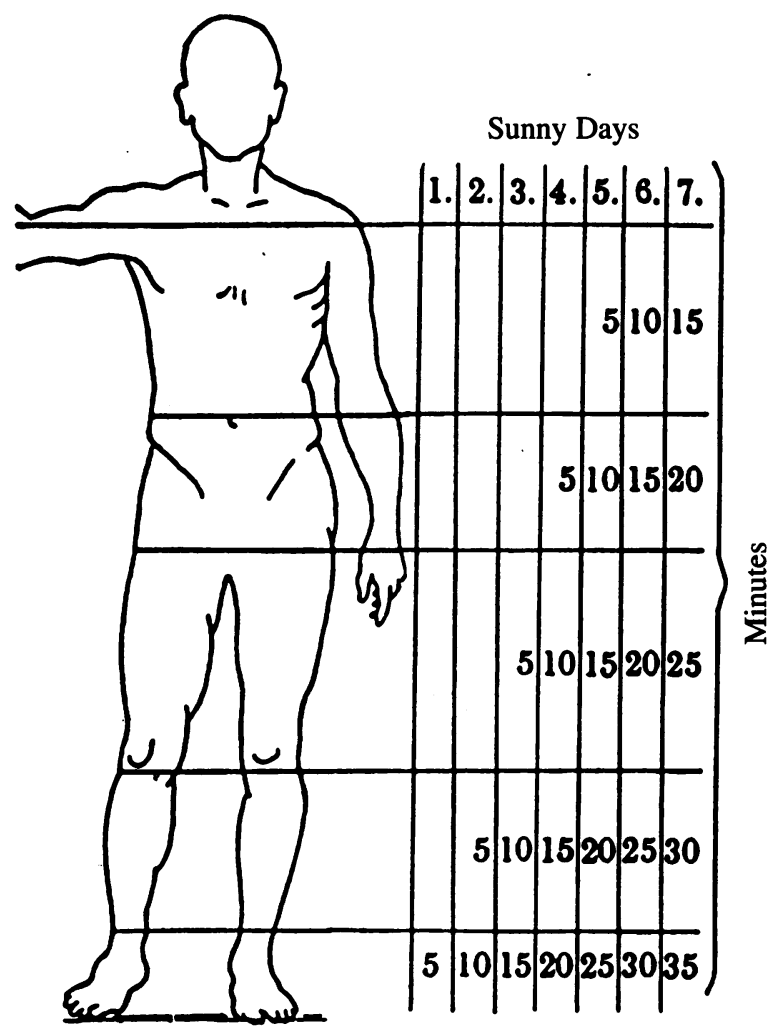

Figure 1: Diagrammatic representation of the Rollier method of sunlight therapy. The patient was covered with a white sheet. On the first day of treatment the sheet was raised to just above the ankles and the patient exposed to direct sunlight for five minutes. On the second day this exposure was repeated and the sheet raised to knee level for a further exposure of five minutes. This progression continued for three weeks after which the full sun-bath was given. (After A Rollier, Heliotherapy, London, 1923.)

Rollier emphasized that this diagram was a general indicator, and did not make allowance for all the factors which had to be assessed before the sun-cure could commence: the age and condition of the patient; the nature of the tuberculosis; the person's tolerance to sunlight; and any variations in atmospheric conditions. The altitude of the sun, together with air-temperatures, air-movement, and the clarity of the atmosphere had also to be taken into consideration. 49

For the average patient, fifteen days of treatment were required before the entire body could be exposed from the start of the sunbath. A daily total of two to three hours of sunbathing was then considered to be sufficient in the summer months, and three to four hours in the winter. Much depended on the rate at which the patient developed a tan: after a period of about ten days the tolerance of the patient to sunlight was assessed and, if the pigmentation was rapid, the treatment had progressed well and the exposure was

${ }^{49}$ Rollier, op. cit., note 39 above, p. 22. 


\section{Sunlight Therapy and Solar Architecture}

increased. Patients whose skin reddened rather than browned were at risk of erythema, and the treatment had to progress with great caution. ${ }^{50}$

Rollier's heliotherapy was combined with a very modified form of orthopaedic splinting. He abandoned plaster of Paris and any other conventional forms of dressing he considered incompatible with sunlight treatment, and developed methods of extension and fixation which permitted free access of sun and air to the body:

... a plaster-of-Paris dressing robs of sunlight precisely those parts of the body which require it most. Its results are first a decline and then a cessation of cutaneous function, severe anaemia, and not infrequently even maceration of the skin; further, sluggishness of nutrition in all regional tissues combined with a diminished excretion of metabolic end-products, the intensity of which processes diminishes pari passu with the withdrawal of light and sunshine. ${ }^{51}$

\section{Heliotherapy of Pulmonary Tuberculosis}

The treatment of pulmonary tuberculosis with sunlight was attempted and abandoned by many physicians in Switzerland and elsewhere. Although good results were reported, it could be extremely hazardous: insolation of the upper body had to be carried out with great care, as premature exposure could result in haemoptysis, haemorrhage, or reactivation of quiescent disease and a spread of infection. A great deal depended on the very careful selection of cases and the meticulous application of sunlight. ${ }^{52}$ Not surprisingly, Rollier was convinced of the benefits of heliotherapy for the majority of pulmonary tuberculosis patients: it was only when a patient was very weak, feverish and toxaemic that the sun-bath was liable to do more harm than good. He claimed that even with patients subject to haemoptysis, a carefully controlled course of sun-baths would cause this tendency to disappear. ${ }^{53}$

In the 1920s it was estimated that some 30 per cent of the patients who were given heliotherapy by Rollier were "surgical" cases complicated by pulmonary tuberculosis, albeit a benign form of the disease. ${ }^{54}$ Rollier's apparent success with heliotherapy can be attributed to the way in which the dosage of sunlight was scrupulously graded by him according to the response and requirements of each patient. The caution with which he approached exposure of the upper body to sunlight was a particular characteristic of his treatment: "The sun should be dispensed, so to speak, drop by drop, when nearing the region of the thorax." 55 He was also insistent that a combination of hot air and sunshine was bad for any form of tuberculosis, but particularly dangerous for the pulmonary form of the disease. This is why he considered it so important to make use of the early morning sun in warm weather. ${ }^{56}$

\section{The "Pansement Solaire" and the "Work Cure"}

During the First World War Rollier used sunlight at his institutions for the aftertreatment of intractible war wounds. He coined the expression "Le Pansement Solaire"-

50 Ibid., p. 24.

51 Idem, op. cit., note 42 above, pp. 49-50.

$52 \mathrm{E}$ Mayer, Sunlight and artificial radiation, London, Baillière, Tindall and Cox, 1926, pp. 205-9.

\footnotetext{
${ }^{53}$ Rollier, op. cit., note 39 above, pp. 109-10.

54 Mayer, op. cit., note 52 above, p. 205.

${ }^{55}$ Rollier, op. cit., note 45 above, p. 745.

${ }^{56}$ Idem, op. cit., note 39 above, p. 110.
} 
"sun-bandage" or "sunlight-dressing"-for the heliotherapy of wounds which he described in his book of the same name published in 1916.57

Rollier held the view that patients' morale played an important part in their cure and was one of the first physicians to introduce what is now termed rehabilitation into the treatment of tuberculosis. His patients were often separated from their families for years at a time and he believed that occupational therapy, his "Work Cure", helped to relieve the loneliness, boredom and financial anxiety which often arose. ${ }^{58} \mathrm{He}$ was concerned that when his patients were cured they had skills which would help them to earn a living again. ${ }^{59}$ Indeed, one of the advantages he ascribed to his non-operative method of treating tuberculosis was that patients were not left permanently handicapped and unable to work:

Heliotherapy is the highest expression of conservative surgery and orthopaedics and has the following advantages over operative measures. It avoids irreparable mutilations and conserves the maximum of articular function (we even find a remarkable return of function in many articulations that had been absolutely ankylosed); it restores to the organism the harmony of its lines, and gives back to the world, not incomplete and deformed beings but normal individuals, capable of earning their living. 60

Two aspects of Rollier's work distinguish him from other physicians who used sunlight to treat disease. First, he believed that sunlight was central to the treatment and could cure tuberculosis. ${ }^{61}$ Second, he was strongly opposed to the use of surgery in all but the most severe cases. His revolt against the wholesale use of surgery was regarded as extreme, and his methods were not accepted for many years. When he presented his first results in Paris in 1905 it is said that the entire audience walked out. ${ }^{62}$ Doctors had great difficulty in coming to terms with such a seemingly unscientific form of treatment. More importantly perhaps, unlike surgical intervention, slow, careful tanning of the skin offered little prospect of sudden recovery or dramatic cures. ${ }^{63}$

Whatever the merits of Rollier's ideas on sunlight and health, there is little doubt that he and his staff at Leysin were able to transform weak, sickly tubercular patients into strong, deeply-tanned individuals who were free of the disease. He also reported success in treating a number of non-tubercular conditions including rickets, war wounds, burns, varicose ulcers, osteomyelitis, septic abscesses and fractures. ${ }^{64}$ Rollier practised sunlight therapy at Leysin for over forty years and had thirty-six clinics with a total of more than 1,000 beds. Each of his clinics was arranged to allow prolonged exposure to sunlight and each was similar in design to one of the three types briefly described below. ${ }^{65}$

\section{Le Chalet}

Rollier's first clinic Le Chalet, a converted boarding house, opened in 1903. This was claimed to be the first clinic devoted exclusively to the systematic treatment of surgical

\footnotetext{
${ }^{57}$ Idem, Le Pansement solaire, Lausanne and Paris, Payot, 1916.

${ }^{58}$ Idem, op. cit., note 39 above, pp. 143-8.

${ }^{59} \mathrm{Op}$. cit., note 32 above.

${ }^{60}$ Auguste Rollier, 'Tuberculosis finds cure in the Leysin heliotherapy clinics', Mod. Hosp., 1923, 21 (3): 255-60, p. 255.
}

\footnotetext{
${ }^{61}$ Idem, op. cit., note 51 above, p. 48.

${ }^{62}$ De Kruif , op. cit., note 35 above, p. 304.

63 Ibid.

${ }^{64}$ Rollier, op. cit., note 51 above, pp. 258-85.

$65 \mathrm{Idem}$, 'The construction of an institution for the heliotherapeutic treatment of surgical tuberculosis', Tubercle, March 1921: 241-50.
} 


\section{Sunlight Therapy and Solar Architecture}

tuberculosis with sunlight. It was in this simple building that Rollier obtained most of the cures which established his international reputation. He proposed Le Chalet as a model for those wishing to start a practical and inexpensive sanatorium where sunlight therapy could be practised.

Le Chalet could accommodate about fifty patients; the first floor was reserved for children and the upper storey for adults. Large south-facing balconies were added to the first floor so that patients' beds could be wheeled out into the sun. The conversion from chalet to sanatorium also included the removal of partition walls to create large dormitories, and all the windows were substantially enlarged. The second floor balconies could not be made wide enough to accommodate all the patients from adjacent rooms, so a large roof-solarium was built where patients could sunbathe from morning to evening. ${ }^{66}$

\section{Les Chamois}

Another building converted for heliotherapy was Les Chamois, which opened in 1909 and was originally an Alpine tourist hotel. Its south-easterly orientation meant that sunbathing could start at sunrise during the summer months, but also that its main balconies were out of the sun during the latter part of the afternoon. This difficulty was resolved by constructing a solarium on each floor on the south-west end of the building. These south-west facing solaria were considered to be particularly useful in winter when the sun-cure could not be carried out on the main balconies in the early morning, due to the low air-temperature. Each solarium was divided into compartments to which patients could be wheeled in their beds for heliotherapy treatment.

\section{Les Frênes}

Les Frênes was probably the first large purpose-built sunlight therapy clinic to be constructed in Europe. It was built in 1911 and consisted of a central, south-facing block and two large wings. The left wing faced south-east and its upper floors had large uncovered terraces which could be used for sun treatment all the year round. It was in this part of the building that the early morning treatment of the summer months, so favoured by Rollier, was undertaken. The terraces offered little protection from the wind and summer sunshine, so they were used by patients who were well-used to sun treatment, or who were not seriously afflicted by tuberculosis. This wing also contained consulting rooms, radiographic departments, rooms for orthopaedics and phototherapy, a bacteriological laboratory, kitchens and offices. On the first floor there was a large hall where patients could be brought to attend films and other forms of entertainment. The clinic's central section contained accommodation for non-patient guests, and a reception area. On the fourth floor there was a room for surgical dressings and an operating theatre.

The right wing of Les Frênes faced south-west. Four of its five floors were occupied by patients. There were eight bedrooms on each of the three upper floors and these were reserved for adults. Each room had a private covered balcony. Partitions between the balconies could be removed so that, as in the case of the first floor which was reserved for children, a large recreation or teaching space could be made. The amount of sunlight these

${ }^{66}$ Idem, op. cit., note 60 above, p. 256. 


\section{R A Hobday}

bedrooms received was limited because of their orientation. However, they were more sheltered than the terraces on the left wing and better suited to winter treatment. To compensate for the lack of sun in these covered balconies during the summer months, bedridden patients could be brought up by lift to a solarium which covered the whole roof of the clinic. The solarium included a covered gallery to provide shelter from the sun, and an arrangement of curtains to give a degree of privacy. The solarium was also used as a play area and by patients who were making their first attempts at walking and needed an absolutely flat surface. Solaria roofs of this type were a feature of all Rollier's clinics.

\section{The International Factory Clinic, the School in the Sun and the Military Clinics}

There was also an International Factory Clinic at Leysin, where patients of limited means could undertake light industrial work to contribute to the cost of their treatment and education. In addition, Rollier established a preventorium or "School in the Sun" at Cernat, about one hour's travel from Leysin. Again, this was a simple large mountain chalet converted into a school. It served the dual purpose of providing a place where children who were considered to be predisposed to tuberculosis could receive preventative sunlight treatment and be educated, and where convalescent patients could prepare for their return to normal life. In addition, two of the clinics under Rollier's direction were maintained by the Swiss government for its tubercular soldiers. ${ }^{67}$

As far as tuberculosis of bones and joints was concerned, three schools gradually developed within the medical profession. The first emphasized the need for surgical intervention in all cases: its adherents believed that a cure could be obtained only through ankylosis and that ankylosis was more rapidly and safely produced by the surgeon's knife than by natural processes. The second school, exemplified by Rollier, accepted that surgery had a part to play, but only a very limited one given the great reliance placed on the healing power of sunlight. The third school adopted a more moderate approach and combined surgery with conservative methods such as solar therapy and artificial light therapy-and in some cases used the plaster-of-Paris cast. ${ }^{68}$ Rollier was, in effect, the arch-conservative with an almost religious enthusiasm for heliotherapy which led to him being described as the high-priest of a solar cult with a world-wide following. ${ }^{69}$

The leading practitioner of heliotherapy in Britain, Sir Henry Gauvain (1878-1945), considered sunlight therapy to be of great value in all cases where the natural resistance of the patient to disease needed to be improved, ${ }^{70}$ but he did not share Rollier's belief that sunlight could cure surgical tuberculosis. In an article to The Times of 11 May 1922 he outlined his approach to heliotherapy and argued for its wider adoption:

Sunlight stimulates and enlivens; it is of help in almost all conditions. It is the greatest of all natural tonics-like good champagne, it invigorates and stimulates; indulged in to excess it intoxicates and poisons. In suitably graduated doses, which vary greatly in individual cases, cumulative and favourable effects are produced which are not accompanied by those unfortunate sequelæ associated with many drugs. Sunlight and fresh air are such valuable therapeutic agents that the extravagant

\footnotetext{
${ }^{67} \mathrm{R}$ A Houston, Light and colour, London, Longmans, Green, 1923, p. 149.

${ }^{68}$ Mayer, op. cit., note 52 above, pp. 210-13.

${ }^{69}$ A Morland, 'Auguste Rollier, M.D.', Br. med.
}

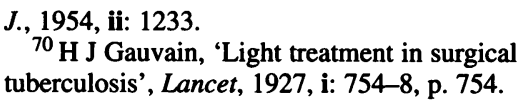

${ }^{70} \mathrm{H}$ J Gauvain, 'Light treatment in surgical tuberculosis', Lancet, 1927, i: 754-8, p. 754. 
claims made by enthusiasts are not only wholly unnecessary, but actually may defeat their object. Statements such as "the sun will cure all forms of surgical tuberculosis" are exaggerations, are contrary to fact, and, if persisted in, will tend to bring into disrepute a method of treatment of the highest value, but possessing definite limitations. In suitably selected cases, graduated and skilled exposure to sunlight aids and accelerates the cure of surgical tuberculosis, both by the beneficent local reaction it produces and by its effect on the general well-being. So also will many other conditions respond, and it is for the general recognition and wide application of this potent natural therapy that I plead. ${ }^{71}$

\section{Sir Henry Gauvain and Lord Mayor Treloar Hospital}

Henry Gauvain was born in the Channel Island of Alderney on 28 November 1878, the eldest surviving son of Captain William Gauvain, the Receiver-General for the Island. While at preparatory school in England he suffered a severe attack of scarlet fever and so was educated privately in Alderney and London, before winning a scholarship to Cambridge. He graduated with a first-class degree in 1902 and then went to St Bartholomew's Hospital where he qualified in 1906, and where he served as house surgeon, midwifery assistant, and clinical assistant in the orthopaedic department. ${ }^{72} \mathrm{He}$ was appointed Medical Officer to the Lord Mayor Treloar Hospital for Crippled Children at Alton, Hampshire, on its foundation in 1908. Gauvain approached heliotherapy somewhat differently from Rollier in that he combined exposure to sunlight and fresh air with sea bathing. Patients, typically tubercular children, started their treatment with gradual exposure to sunlight for a long period inland at the main hospital at Alton. They were then transferred to an establishment on the south coast at Hayling Island where the sea-bathing treatment took place. ${ }^{73}$

Gauvain was actively involved with the architect H C Smart in the design of the building which replaced the original hospital at Alton, and his views and recommendations on the design and use of balcony wards for the chronically ill are particularly noteworthy. The new hospital building was completed in 1933 and consisted of five similar ward units, of 60 beds each, arranged along a terrace some 1,000 feet long. A pavilion system was adopted for the hospital as this eased the transport of patients to and from the terrace. It was also much safer in the event of fire than a multi-storey building as there was no need to use lifts and stairs to transport the predominantly bedridden patients. In addition, pavilion planning allowed the wards to be cross-ventilated, which was considered to be an important hygienic safeguard. The hospital faced southeast to ensure the maximum of early morning sunlight for the patients in the wards, or on the terrace. ${ }^{74}$ Gauvain felt that most open-air hospitals were unsuitable for sunlight treatment and designed special wards to try to overcome the limitations of more conventional designs:

\footnotetext{
${ }^{71}$ Idem, 'The sun cure-ailing children's new hope', The Times, 11 May 1922: 17-18, p.17.

72 D Power, 'Sir Henry John Gauvain (1878-1945)', in Lives of the Fellows of the Royal College of Surgeons of England, London, Royal College of Surgeons of England, 1953, p. 317.
}

\footnotetext{
${ }^{73}$ G S E Moynihan, Lord Mayor Treloar Hospital and College, Southampton, Paul Cave Publications, 1988, pp. 14-35, 45-50.

${ }^{74}$ H J Gauvain, 'Planning a hospital', Lancet, 1938, ii: pp. 95-8.
} 


\section{R A Hobday}

Open-air hospitals are too often draughty and cheerless buildings, damp in wet weather, cold in cold weather, unduly hot in hot weather. Balcony accommodation is often woefully deficient and badly planned. Patients who should be kept immobile have to be wheeled to reach the sunshine through narrow doorways and round awkward corners. ${ }^{75}$

It was his opinion that suitable patients should live in the open, stimulated by sunlight and fresh air, but sheltered from inclement weather. Gauvain determined that patients could be exposed to sunlight in one of two ways: either by wheeling them from the wards to adjacent balconies; or by leaving them where they were and "removing" the wards. He had experimented with ward design at his private clinic at Alton and at King George's Sanatorium for Sailors, Bramshott. Here he had constructed an "all weather" balcony ward which was designed to be open to the elements, or entirely closed, or altered to any intermediate position. ${ }^{76}$ The ward had a sliding roof of "Vita-glass"-which transmitted ultra-violet light - and a canvas awning to provide shade. The walls above bed level consisted of folding glass panels. The walls also incorporated hinged flaps six inches from the floor which were designed to admit fresh air and keep out rain. These flaps, together with louvres in the roof were intended to keep the wards ventilated when the roof was down and the sliding windows closed.

The wards of the new Treloar Hospital building were built on similar principles in an attempt to combine "permanent structure and successful architectural treatment with maximum convenience and efficiency, as well as the maximum of open air and light". 77 The south face of each ward was entirely glazed, consisting of folding glazed doors with windows above. The latter were rainproof and, together with windows on the north side of the ward, could be opened for cross-ventilation when the folding doors were closed. The terrace in front of the wards was 25 feet wide and covered to a depth of 10 feet by a sliding terrace roof of wired Vita-glass. Bed-ridden patients could be pushed out from the wards with the minimum of effort and, if rain or snow fell, the terrace roof could be lowered to provide protection. Canvas blinds below the sliding roof could be lowered or raised to admit sunlight as required. Together with curtains which could be drawn over the folding glazed doors, these blinds ensured that the ward could be completely darkened as: "there must be free access to sunlight and yet adequate provision of shade, for in sun treatment darkness is, in my opinion, as essential as light, and excess of sunlight may be even more harmful than its lack". ${ }^{78}$

The wards were designed with high ceilings so that the cross-ventilation system would provide a supply of gently moving air, without draughts. It was felt that dormitory and ward infections would then have less chance of developing. Radiant panels in the walls of the wards supplied heating which was intended to keep out the damp and keep the feet of patients warm and their heads cool. In addition, each ward was provided with an open fireplace: the psychological effect of a radiant heat source was felt to be considerable, especially on dull and dreary winter days.

The wards were designed for the treatment of chronic patients, particularly adolescents and young adults who were recovering from surgical tuberculosis or were approaching convalescence. Gauvain recognized that, while wards of this type would be of great value at

\footnotetext{
75 Idem, 'Open-air country hospitals for children', Lancet, 1933, i: $321-5$, p. 321.

${ }^{77}$ Ibid., p. 322.

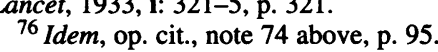

${ }^{78}$ Ibid., p. 321.
} 


\section{Sunlight Therapy and Solar Architecture}

a conventional hospital, they were unsuitable for the very ill, or rapidly deteriorating patient for whom sunlight and an open-air regime were contraindicated. As Gauvain acknowledged, "A very sick person who lacks the power of response to such stimuli must conserve his resources and should not be exposed to such a strong tonic until adequate powers of response have been acquired." 79 Nevertheless, his experience in treating the chronically ill in balcony wards convinced him of the need for such accommodation in hospitals:

. . . if I may express my conviction, the most urgent and human need of most modern hospitals is the general lack of properly planned and protected balcony accommodation. Really to appreciate that need one should be a patient as well as a doctor. The advantage of getting into the open air, away from the sight, sounds and smells of the sick room, must be experienced to be understood, and in my opinion this is a factor insufficiently recognised in practice. ${ }^{80}$

\section{Heliotherapy and Modern Architecture}

Bernhard, Rollier and Gauvain emphasized the important role sunlight could play in the prevention as well as the treatment of tuberculosis, and were advocates of sunlit, wellventilated buildings. Rollier's views on the need for sunlight and fresh air in dwellings are outlined in his book Quarante ans d'héliothérapie, ${ }^{81}$ and in the conclusion of his paper on heliotherapy in the British Medical Journal of 1922:

These elements should have a larger place given them, in daily life and in the city. Not only modern towns should be built on such hygienic principles, but also the home. Housing has played an immense part in the genesis of child and adult tuberculosis: the community bears the responsibility of the waste of human lives through insanitary houses. ${ }^{82}$

Sir Henry Gauvain was of the view that the design principles adopted in his wards should be applied to hospitals and residential accommodation of all kinds, including private houses and schools: "There is no doubt that living under such conditions many hospital patients would be restored to health more speedily, that the pupils in schools would be sturdier, healthier, happier, and less prone to infectious disease than at present, and that the community as a whole would benefit." 83

Gauvain's work with heliotherapy and hospital design did have some influence on the architectural profession. He was invited to write the Foreword to The orientation of buildings by the Royal Institute of British Architects which was the first publication to give architects and planners authoritative guidance on the design of sunlit buildings. ${ }^{84}$ In this report, published in 1933, great emphasis was placed on the virtues of sunlit dwellings and the limitations of conventional hospital buildings in this respect. ${ }^{85}$ The authors were also critical of designs which admitted too much sunlight, and of one architect in particular-Le Corbusier: "It may be some time before we can all say with Corbusier ' $\mathrm{Je}$ dessine avec la lumière'. Possibly if we are wise we never shall." 86

${ }^{79}$ Idem, 'Planning a hospital', Trans. med. Soc. Lond., 1938, 61: 246-61 p. 249.

${ }^{80}$ Ibid., p. 260-1.

81 Auguste Rollier, Quarante ans d'héliothérapie, University of Lausanne, 1944, pp. 151-3.

82 Idem, op. cit., note 45 above, p. 745.

${ }^{83}$ Gauvain, op. cit., note 75 above, p. 325 .

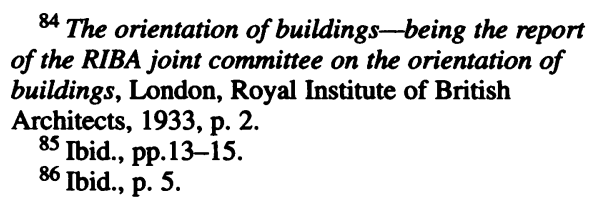

${ }^{84}$ The orientation of buildings-being the report of the RIBA joint committee on the orientation of buildings, London, Royal Institute of British Architects, 1933, p. 2.

${ }^{85}$ Ibid., pp.13-15.

${ }^{86}$ Ibid., p. 5. 


\section{R A Hobday}

Le Corbusier (1887-1965) was one of the most influential architects of the twentieth century. ${ }^{87}$ Whatever the merits of his buildings, it is evident throughout his extensive writings that he had a preoccupation with sunlight and that this was due, in part, to a concern about the dangers of tuberculosis. This is manifest in the book he wrote in the 1950s on one of his most important buildings, the "Unité d'habitation" or Marseille Block: "Doling out cosmic energy, the sun's effects are both physical and moral, and they have been too much neglected in recent times. The results of that neglect can be seen in cemetery and sanatorium." 88 The Marseille Block, a large apartment building of eighteen floors, shared many of the features of a heliotherapy clinic. It was carefully orientated for sunlight: balconies served as sun-screens or brise-soleil and were designed to allow sunshine into the apartments in winter while providing shade in the summer months. They also provided an "open-air extension" of each living room. ${ }^{89}$ In addition, the Marseille Block had a terraced roof which provided a range of amenities for the residents, including a solarium. ${ }^{90}$

Much earlier in his career, Le Corbusier had been associated with another architect who made provision for sunlight therapy in his work. Tony Garnier (1869-1948) earned his place in the vanguard of the Modern Movement by being one of the first architects to build in concrete without concealing the material and without adapting it to conform with previous architectural styles. ${ }^{91} \mathrm{He}$ also produced one of the most influential plans for an idealized modern city; the "Cité Industrielle". Garnier's reputation as a pioneer of urban planning and modern architecture, and the influence of his Industrial City on later planners, owes a great deal to the recognition given to this work by Le Corbusier. ${ }^{92}$ The "Cité Industrielle" project began in 1901 when Garnier was a Pensionnaire at the Académie de France in Rome. Detailed plans and perspective drawings were exhibited in 1904 and he continued to work on them until their publication in $1917 .{ }^{93}$ Garnier was City Architect of Lyon from 1905 to 1919, carrying out a number of projects which drew from the ideas formulated in his Industrial City. ${ }^{94}$

The Cité was oriented for the maximum of sunlight and was composed of a grid of parallel and perpendicular streets. Garnier specified that its houses and public buildings were to receive direct sunlight for the purpose of sanitation. It would be an exaggeration to say that the Cité was conceived as a giant sanatorium, but the way in which the buildings were designed owes a great deal to sanatorium architecture. Significantly, the Cité's hospital complex included an "heliotherapeutic" building which would have been used for the purposes of preventing or treating tuberculosis. It seems reasonable to suggest that this was one of the additions made to the plans between their exhibition in 1904 and publication in 1917 , as sunlight therapy was not in widespread use much before the second decade of this century.

\footnotetext{
${ }^{87} \mathrm{P}$ Nuttgens, Understanding modern architecture, London, Unwin Hyman, 1988, p. 96.

${ }^{88}$ Le Corbusier, The Marseille block, transl.

G Sainsbury, London, Harville Press, 1953, p. 21.

${ }^{89}$ André Wogenscky, in ibid., p. 52.

90 Ibid., p.58.

${ }^{91} \mathrm{~N}$ Pevsner, Pioneers of modern design,
}

Harmondsworth, Penguin, 1974, p. 179.

${ }^{92} \mathrm{D}$ Wiebenson, Tony Garnier: the cité industrielle, London, Studio Vista, 1969, p. 98.

${ }^{93} \mathrm{D}$ Sharp, Sources of modern architecture, 2nd ed., London, Granada, 1981, p. 46.

${ }^{94}$ Ibid., p. 46. 


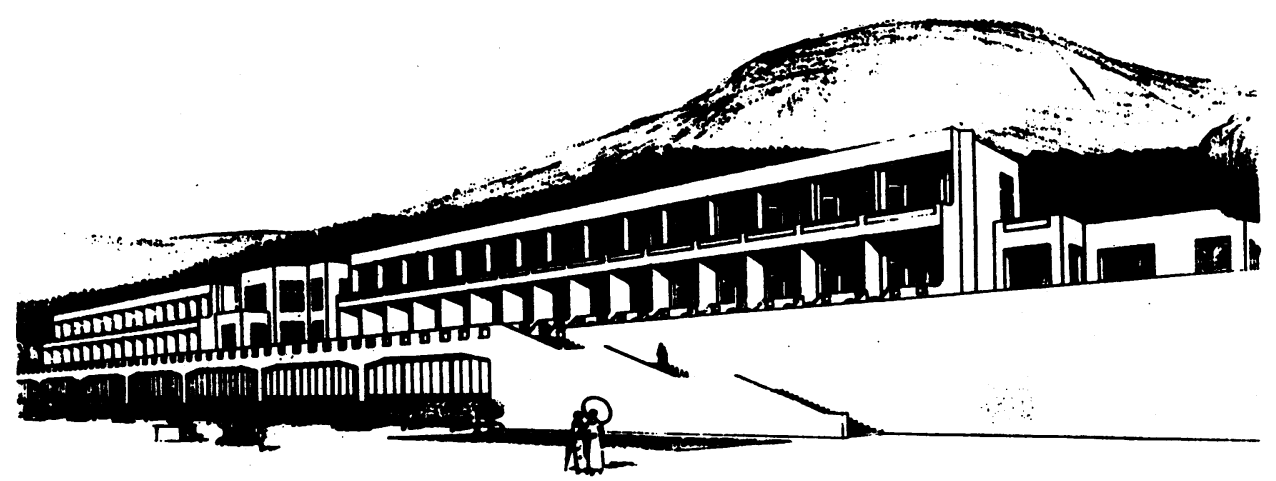

Figure 2: The heliotherapy clinic from Tony Garnier's Cité Industrielle of 1917. (From D Wiebenson, Tony Garnier: the cité industrielle, London, Studio Vista, 1969.)

\section{The Decline of Sunlight Therapy and Solar Architecture for Health}

So, as well as establishing sunlight therapy as a preventative and curative measure for tuberculosis in the years before the development of chemotherapy, Oskar Bernhard, Auguste Rollier and Sir Henry Gauvain may have had some influence on the course of twentieth century architecture. After the Second World War, increased public health provision and improved standards of living led to a marked decrease in the incidence of diseases such as tuberculosis. Medical practice changed and one consequence of this is that the hygienic and medicinal properties of sunlight have had little influence on building design. Currently, solar architecture is usually associated with energy conservation rather than health. Sunlight penetration into buildings is often regarded qualitatively as "beneficial" or "desirable" but this aspect of design appears to receive a low priority compared with other environmental factors. Little contemporary evidence exists to support the need for sunlight; the nature of any supposed benefits, other than psychological, is not altogether obvious to the reader of much of the current literature on sunlight in buildings. ${ }^{95}$

\section{Conclusions}

Little more than fifty years ago sunlight was considered to be an important medicine and an aid to hygiene. Many of the better hospitals and sanatoria constructed for the treatment of tuberculosis were, effectively, solar buildings. Physicians such as Oskar Bernhard, Auguste Rollier and Sir Henry Gauvain emphasized the important role sunlight could play in the prevention and treatment of the disease and were advocates of sunlit, well-ventilated buildings. This is reflected in the hospitals and clinics they helped to design; and their work also appears to have had some influence on the development of modern architecture and town planning.

\footnotetext{
${ }^{95}$ R A Hobday, 'Sunlight, health and energyefficient buildings', Int. J. Ambient Energy, 1992, 13 (3): 125-31.
} 


\section{R A Hobday}

There has since been a complete reversal in medical thinking on sunlight. Sunbathing is now regarded by many experts as a dangerous pastime which should be actively discouraged and sunlit buildings are the exception rather than the rule. The reasons for this profound change are many and varied and beyond the scope of this paper. However, a factor which should not be ignored is that the physicians who used sunlight on war wounds and diseased bones and joints at the beginning of this century lacked a scientific theory with which to explain the effectiveness of sunlight therapy and had to rely on a largely empirical approach. One consequence of this is that it has been easy for subsequent generations to ignore or dismiss their methods and their results. Whether it was effective or not, the fact remains that, for a period, sunlight therapy was a popular form of treatment and it produced some notable solar architecture. 